\title{
ROLE OF A MAX YEAST CULTURE PROBIOTIC IN POTENTIATING THE GROWTH PERFORMANCE OF COMMERCIAL BROILER
}

\author{
M. R. Islam, M. Mostofa*, S. Islam, R. R. Roy, M. G. Sorwar and K. S. Mondal \\ Department of Pharmacology, Bangladesh Agricultural University \\ Mymensingh-2202, Bangladesh
}

\begin{abstract}
The present study is under taken to determine the body weight gain of broilers, to determine carcass yield or dressing percentage of broilers, to determine feed conversion ratio of broilers, to enumerate the colonizing micro flora in the gut of broilers. A total of 80 day-old broiler chicks were divided into two main groups I and II with 40 chicks in each. Group I was supplemented with Probiotic (Max Yeast Culture gm $/ \mathrm{kg}$ feed) containing feed and chicks of group II was supplemented with conventional feed. Group I and II was again subdivided into two subgroups as group A, B and C, D respectively on 6 days of age. Birds of subgroups A and C were vaccinated with $N D$ vaccine (BCRDV) and birds of subgroups $C$ and $D$ were kept as unvaccinated. The result evidenced the following information: (a) The total viable count $($ TVC) and total coliform count $($ TCC) were significantly $(\mathrm{P}<0.01)$ lower in experimental birds as compared to control at 14, 28 and 32 days of age both in vaccinated and non-vaccinated birds. It was always found that the lower TVC in probiotic fed broilers as compared to conventional fed broilers (b) The total lactobacilli count $(\mathrm{TLC})$ was significantly $(\mathrm{P}<0.01)$ higher in experimental birds as compared to control at 14, 28 and 32 days of age both in vaccinated and nonvaccinated birds. So it can be said that Max Yeast Culture supplementation can reduce the growth of pathogenic microorganism and increase the growth of beneficial microorganism
\end{abstract}

Key Words: Probiotic, Broiler, Broiler growth

\section{INTRODUCTION}

Bangladesh is an agro-based country. About $85 \%$ of total population is engaged in agricultural production. According to the Bangladesh Economic Survey, contribution of agriculture to GDP growth declined further to 19.29 per cent in FY2011-2012 ... (crop, livestock, forestry and fisheries) to GDP was 21.77 per cent. Poultry industry has emerged as an agri-business sector started practically during 1980 in Bangladesh. Although poultry industry is expending in Bangladesh, it is facing a lot of constraints. Quality feed is a major problem, which has direct influences on production cost. Feed additives, like antibiotics, hormones and corticosteroids are used in the diet of poultry to improve the performance of poultry production but antibiotics and hormones have harmful effects on poultry as well as human health after consumption. Recently it is believed that probiotic have beneficial

${ }^{*}$ Corresponding author (Email: mostofa57@yahoo.com) 
effects to improve the productive performance of poultry. A great deal of attention has recently been received from nutritionists and health care experts for proper utilization of nutrients and the use of probiotic for growth promotion of poultry Kabir (2005). The present study is attempted to evaluate the effect of probiotics with regard to clearing bacterial infections and regulating intestinal flora by determining the total viable count (TVC) and total lactobacillus count (TLC) of the crop and cecum samples of probiotics and conventional fed groups Kabir (2005).

\section{MATERIALS AND METHODS}

\section{Experimental birds}

Day-old "Ross 308" broiler chicks were purchased from local sale central market in Gazipur, Bangladesh and transported carefully to the Poultry Shed of the Department of Pharmacology, Bangladesh Agricultural University, Mymensingh, in well-ventilated paper cartons. The birds were reared under hygienic management practices throughout the entire period of study.

\section{Diets}

Commercially available poultry feed (Quality Feeds Ltd., Dhaka) was used throughout the experimental study. The broiler chicks were fed with standard broiler starter up to 14 days and broiler grower from 15-32 days of age, as formulated by Quality Feeds Ltd., Dhaka.

\section{Probiotic}

A Max Yeast Culture ${ }^{\mathrm{TM}}$ marketed by Wilts Marketing Co., Ltd. and manufactured by Varied Industries Corp, USA was used in this study. A minimum of $1.5 \times 10^{12} \mathrm{CFU} / \mathrm{g}$ (Colony Forming Units) is present in A Max Yeast Culture ${ }^{\mathrm{TM}}$. It is manufactured using a proven strain of Saccharomyces cerevisiae, grown on a media of corn germ meal, sucrose, cane molasses, and corn syrup, dried in such a manner as to preserve its fermenting activity for a long time.

\section{Management}

Probiotic was added in feed at a level of $2 \mathrm{~g} / \mathrm{kg}$ and was given to birds of Group I up to 32 days of age. The remaining Group II was kept as control without adding probiotic in feed.

\section{ND Vaccine}

Bangla BCRDV was collected from Microbiology laboratory of BAU, Mymensingh, Bangladesh. FnF Pharmaceuticals Limited, Jhenidah, Bangladesh, manufactured Bangla BCRDV. Birds of subgroup A and $C$ were vaccinated with BCRDV through intraocular route.

\section{Body weight of birds}

The live body weight of five birds from each subgroup was taken with the help of standard balance. The body weight of birds was taken at 7 days interval from day 0 to 32 . 
Carcass yield and cut up meat parts: Five birds from each subgroup were sacrificed randomly on the $14^{\text {th }}, 28^{\text {th }}$ and $32^{\text {nd }}$ days of age. Birds were dissected according to the procedure described by Jones (1984). After removing the skin, head and viscera, then final processing was performed and carcass yield was recorded by using electrical weighing balance. Weight of cut up meat parts such as leg and breast was calculated separately.

\section{Statistical data analysis}

Data were analyzed using SPSS v.10 for Windows (SPSS Inc., Chicago, IL, USA). Statistically significant differences between group means were determined by analysis of variance (ANOVA). When the differences were significant, Duncan's multiple range tests was performed. Mean values were considered significantly different at $\mathrm{P}<0.05$. Data are expressed as mean \pm SEM.

\section{RESULTS AND DISCUSSION}

The live weight of birds of probiotic containing feed group (Table 1) were found significantly $(\mathrm{P}<0.01)$ higher than con-ventional feed group (Table 2$)$ by ANOVA on each occasion of observation up to 32 days of age. The live weight gain was found higher in birds of unvaccinated subgroups compared to the birds of vaccinated subgroups, which were supplied with probiotic containing feed. The carcass yields of broilers of all subgroups at different age are shown in Table $1 \& 2$.

Table 1. Effect of probiotic feeding on live weight, carcass yield, cut up meat parts and feed conversion ratio (FCR) of broiler

\begin{tabular}{|c|c|c|c|c|c|c|}
\hline \multirow{2}{*}{\multicolumn{2}{|c|}{$\begin{array}{c}\text { Probiotic fed group } \\
\text { (PFG) }\end{array}$}} & \multirow{2}{*}{$\begin{array}{c}\text { Live weight } \\
\text { (in gm) }\end{array}$} & \multirow{2}{*}{$\begin{array}{c}\text { Carcass yield } \\
\text { (in gm) }\end{array}$} & \multicolumn{2}{|c|}{ Cut up meat parts (in gm) } & \multirow[t]{2}{*}{ FCR } \\
\hline & & & & Leg & Breast & \\
\hline Day 0 & & $85.00 \pm 1.15^{\mathrm{a}}$ & - & - & - & - \\
\hline \multirow[t]{2}{*}{ Day 07} & $\mathrm{~A}$ & $192.25 \pm 3.23 \mathrm{a}$ & - & - & - & 1.52 \\
\hline & B & $200.00 \pm 3.32^{* a}$ & - & - & - & 1.50 \\
\hline \multirow[t]{2}{*}{ Day 14} & A & $550.00 \pm 3.24^{*_{a}}$ & $390.25 \pm 4.14^{\mathrm{a}}$ & $110.45 \pm 4.34^{\mathrm{a}}$ & $93.50 \pm 4.04^{*_{a}}$ & 1.56 \\
\hline & B & $600.75 \pm 4.27 \mathrm{a}$ & $420.50 \pm 4.23^{a}$ & $130.50 \pm 4.14^{\mathrm{a}}$ & $109.25 \pm 4.39^{\star_{a}}$ & 1.55 \\
\hline \multirow[t]{2}{*}{ Day 21} & A & $990.00 \pm 6.56^{a}$ & - & - & - & 1.59 \\
\hline & B & $1070.50 \pm 6.75^{a}$ & - & - & - & 1.59 \\
\hline \multirow[t]{2}{*}{ Day 28} & A & $17000.00 \pm 6.56^{\mathrm{a}}$ & $1330.25 \pm 4.43^{\mathrm{a}}$ & $410.75 \pm 4.14^{\mathrm{a}}$ & $430.25 \pm 3.04^{a}$ & 1.64 \\
\hline & B & $1750.25 \pm 6.82^{a}$ & $1370.50 \pm 4.63^{a}$ & $430.75 \pm 4.14^{\mathrm{a}}$ & $450.25 \pm 3.14^{a}$ & 1.64 \\
\hline \multirow[t]{2}{*}{ Day 32} & A & $2160.00 \pm 3.54^{\mathrm{a}}$ & $1650.75 \pm 4.16^{\mathrm{a}}$ & $510.25 \pm 4.47 \mathrm{a}$ & $550.50 \pm 4.47 a$ & 1.70 \\
\hline & B & $2200.50 \pm 3.32^{a}$ & $1670.75 \pm 3.11^{a}$ & $530.25 \pm 3.17 \mathrm{a}$ & $556.75 \pm 4.17 \mathrm{a}$ & 1.69 \\
\hline
\end{tabular}

The highest carcass yield was found in the birds that fed with probiotic containing feed remained unvaccinated compared to birds of other groups at day 14, 28 and 32 of age. The two prominent cut up meat parts of broilers were also found in higher in birds of subgroup 
B compared to birds of other subgroups on day 14, 28 and 32 of age. The weight of leg and carcass was found significantly $(\mathrm{P}<0.01)$ higher in birds of the probiotic containing subgroups compared to control. Overall it was found that the live weight, carcass yield, weight of cut up meat parts were higher which fed with probiotic containing feed compared to the birds which fed with conventional feed. The feed conversion ratio of probiotic groups were 1.52, 1.56, 1.59, 1.64 and 1.70 in the birds of subgroup A and 1.50, 1.55, 1.59, 1.64 and 1.69 in the birds of subgroup B on day 7, 14, 21, 28 and 32 of age respectively. On the other hand feed conversion ratio was found 1.56, 1.60, 1.69, 1.75 and 1.81 in the birds of subgroup $\mathrm{C}$ and 1.55, 1.61, 1.69, 1.74 and 1.80 in the birds of subgroup D (Table $1 \& 2$ ). It is obvious from the result that the feed conversion ratio was found significantly improve in experimental birds as compared to control birds. The feed conversion ratio was always found slightly improve in birds of unvaccinated birds of both groups compared to vaccinated birds of both groups.

Table 2. Effect of conventional feeding on live weight, carcass yield, cut up meat parts and feed conversion ratio of broiler

\begin{tabular}{lc|c|c|c|c|c}
\hline \multicolumn{2}{c}{$\begin{array}{c}\text { Conventional } \\
\text { fed group (PFG) }\end{array}$} & $\begin{array}{c}\text { Live weight } \\
\text { (in gm) }\end{array}$ & $\begin{array}{c}\text { Carcass yield } \\
\text { (in gm) }\end{array}$ & \multicolumn{2}{c|}{ Cut up meat parts (in gm) } & \multirow{2}{*}{ FCR } \\
\cline { 5 - 6 } Day 0 & & $85.00 \pm 1.10^{\mathrm{a}}$ & - & Leg & Breast & \\
Day 07 & $\mathrm{C}$ & $181.25 \pm 3.10^{\mathrm{a}}$ & - & - & - & - \\
& $\mathrm{D}$ & $190.00 \pm 2.00^{*} \mathrm{~b}$ & - & - & - & 1.56 \\
Day 14 & $\mathrm{C}$ & $480.00 \pm 2.15^{\mathrm{b}}$ & $345.25 \pm 4.04^{\mathrm{b}}$ & $95.25 \pm 3.24^{\mathrm{b}}$ & $105.25 \pm 3.23^{*} \mathrm{~b}$ & 1.60 \\
& $\mathrm{D}$ & $500.75 \pm 4.27 \mathrm{~b}$ & $360.50 \pm 3.32^{\mathrm{b}}$ & $93.25 \pm 3.23 \mathrm{~b}$ & $109.25 \pm 3.23^{*} \mathrm{~b}$ & 1.61 \\
Day 21 & $\mathrm{C}$ & $840.50 \pm 7.56^{\mathrm{a}}$ & - & - & - & 1.69 \\
& $\mathrm{D}$ & $890.50 \pm 7.32^{\mathrm{a}}$ & - & - & - & 1.69 \\
Day 28 & $\mathrm{C}$ & $1390.75 \pm 5.54^{\mathrm{b}}$ & $1000.50 \pm 4.13^{\mathrm{b}}$ & $290.25 \pm 4.24 \mathrm{~b}$ & $340.25 \pm 4.144^{\mathrm{b}}$ & 1.75 \\
& $\mathrm{D}$ & $1420.25 \pm 4.27^{\mathrm{b}}$ & $1040.25 \pm 4.13^{\mathrm{b}}$ & $300.25 \pm 4.24 \mathrm{~b}$ & $350.25 \pm 4.04^{\mathrm{b}}$ & 1.74 \\
Day 32 & $\mathrm{C}$ & $1735.50 \pm 4.23^{\mathrm{b}}$ & $1275.50 \pm 4.40^{\mathrm{b}}$ & $385.25 \pm 4.27 \mathrm{~b}$ & $400.00 \pm 4.02 \mathrm{~b}$ & 1.81 \\
& $\mathrm{D}$ & $1750.50 \pm 4.20^{\mathrm{b}}$ & $1310.50 \pm 3.40^{\mathrm{b}}$ & $400.00 \pm 3.27 \mathrm{~b}$ & $430.00 \pm 3.02^{\mathrm{b}}$ & 1.80 \\
\hline
\end{tabular}

A and C: Vaccinated birds B and D: unvaccinated birds; Means with different superscripts column wise differ significantly at ${ }^{*} \mathrm{P}<0.01$ but means with different superscripts with ${ }^{*}$ column wise differ significantly at ${ }^{*} \mathrm{P}<0.05$.

The live weight gains were significantly $(\mathrm{P}<0.01)$ higher in experimental birds as compared to control at 7, 14, 21, 28 and 32 days of age both in vaccinated and unvaccinated birds. Significantly $(\mathrm{P}<0.05)$ higher live weight gain was observed in the birds, which fed with probiotic containing feed compared to conventional fed group. The average live weight gains were always found slightly higher in unvaccinated birds as compared to vaccinated birds at 7, 14, 21, 28 and 32 days of age. The finding is in agreement with Manickam et al. (1994) who stated that the weight gains of broiler chicks given Lactobacillus sporogenes (probiotic) were significantly better than untreated control group. Higher body weight gains due to probiotic fed broilers were also reported by Singh et al. (1999), Kwon et al. (2002), Kabir et al. (2005) and Zhang et al. (2005). Higher carcass yield was found in broiler chicks fed with the probiotic both in vaccinated and unvaccinated birds compared to conventional 
feed group both in vaccinated and unvaccinated birds at 14, 28 and 32 days of age. The average carcass yield was slightly higher in unvaccinated birds than the vaccinated birds at 14, 28 and 32 days of age. Isik and Ozen (1997), Lee et al. (2002) Kabir et al. (2004) and Zhang et al. (2005) mentioned that dietary probiotic supple-mentation had significant effect on carcass yield of broilers, which is in the agreement with the present study. The two prominent cut up meat parts of broilers were also found in higher in birds of subgroup B compared to birds of other sub-groups. The weight of leg was found significantly $(\mathrm{P}<0.01)$ higher in experimental birds as compared to control ones on the 14, 28 and 32 days of age. Significantly $(\mathrm{P}<0.01)$ higher breast weight in broiler chicks fed with the probiotic was observed on the 14, 28 and 32 days of age compared to control. The present findings indicated that the yield of cut up meat parts was higher in probiotic containing fed groups than control. Similar findings were also demonstrated by Kwon et al. (2002), Kabir et al (2004) and Vicente et al. (2007). The feed conversion ratio was found significantly improve in experimental birds as compared to control birds. The feed con-version ratio was always found slightly improve in birds of unvaccinated birds of both groups compare to vaccinated birds of both groups 7, 14, 21, 28 and 32 days of age. These findings support the finding of Isik et al. (1997); Singh et al. (1999) and Zhang et al. (2005) found that dietary probiotic supplementation had better effect on feed conversion ratio of broilers.

\section{REFERENCES}

Minickam, M., Kahraman, R., Kocabagli, N. and Abas, I. 1994. Supplementing the oxidized broiler fed with vitamin andprobiotic I. Effect on the performance and ascites incidence. Pendik Veteriner Mikrobiyoloji Dergisi, 30(1): 61-65.

Singh, P., Sahoo, J. and Panda, P. C. 1999. Effect of probiotics (Lacto-Sacc) feeding and seasons on poultry meat quality. Indian Journal of Poultry Science, 35(3): 297-301.

Panda, A. K., Reddy, M. R., Rao, S. V. R., Raju, M. V. L. N. and Praharaj, N. K. 2000. Growth, carcass characteristics, immunocompetence and response to Escherichia coli of broilers fed diets with various levels of probiotic. Archiv-fur-Geflugelkunde, 64(4): 152-156.

Patidar, S. K. and Prajapati, J. B. 1999. Effect of feeding lactobacilli on serum antibody titer and faecal microflora in chicks. Microbiologie, Aliments, Nutrition, 17(2): 145-154.

Isik E., M. and Ozen, A. 1997. Effects of a probiotic and other feed additives on performance and immune response of broiler chicks. Iran Int. J. Poult. Sci., 4: 488-492.

Santin, A. C., Paulillo, L. S. O., Nakagui, A. C., Alessi, W. J. C. and Polveiro, A. 2004. Evaluation of cell wall yeast as adsorbent of chratoxin in broilers diets. International Journal of Poultry Science, 3(5): 313-321.

Jones, A. S., Stehman, S. M., Snoeyenbos, G. H., Weinack, O. M. and Smyser, C. F. 1984. The influence of lactobacilli on competitive exclution of paratyphoid salmonellae in chickens. Avian Disease, 25:1227-1033.

Vicente, J. L., Aviña, L., Torres-Rodriguez, A., Hargis, B. and Tellez. G. 2007. Effect of a lactobacillus spp-based probiotic culture product on broiler chicks performance under commercial conditions. International Journal of Poultry Science, 6(3): 154-156. 
Zhang, A. W., Lee D. B., Lee, S. K., ,Lee, K. W., An, G. H., Song, K. B. and Lee, C. H. 2005. Effects of yeast (Saccharomyces cerevisiae) cell components on growth performance, meat quality, and ileal mucosa development of broiler chicks. Poultry Science Association, Inc.

Kabir, S. M. 2005. "The role of probiotics in the poultry industry international journal of molecular sciences." The Agriculturists 2005, 3, 24-29. 15.

Zhang, A. W., Lee, D. B., Lee, S. K., Lee, K. W., An, G. H., Song, K. B. and Lee, C. H. 2005. Effects of yeast (Saccharomyces cerevisiae) cell components on growth performance, meat quality, and ileal mucosa development of broiler chicks. Poultry Science Association, Inc.

Kwon, B. J., Meinersmann, R. J. and Stern, N. J. 2002. Antagonistic effects of Lactobacilli and Pediococci to control intestinal colonization by human entero-pathogens in live poultry. Journal of Applied Bacteriology, 70(2): 95-103. 